\title{
An Analysis of Power Beaming for the Moon and Mars
}

Mark W. Stavnes

Sverdrup Technology, Inc.

Lewis Research Center Group

Brook Park, Ohio

August 1992

Prepared for

Lewis Research Center

Under Contract NAS3-25266
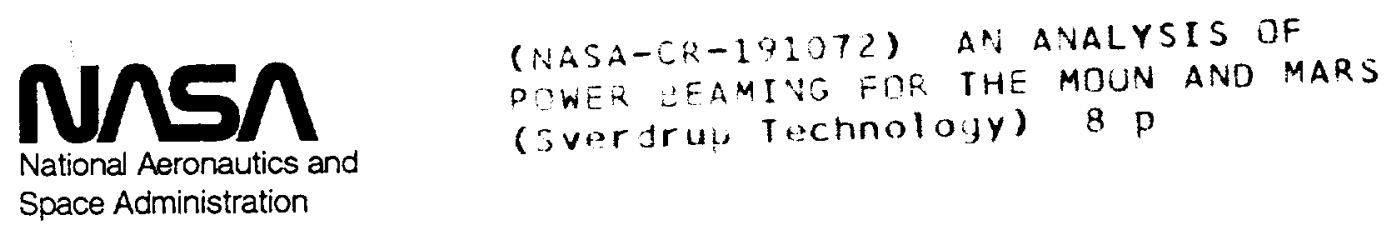



\title{
An Analysis of Power Beaming for the Moon and Mars
}

\author{
Mark W. Stavnes \\ Sverdrup Technology, Inc. \\ Lewis Research Center Group \\ 2001 Aerospace Parkway \\ Brook Park, Ohio 44142
}

\begin{abstract}
Operations on the surface of the Moon and Mars will depend on a reliable source of electrical power. At NASA Lewis Research Center, the feasibility of powering lunar and martian surface sites by power beaming was studied. Constellations of nuclear or solar powered satellites using microwave or laser transmitters were designed to power an equatorial surface base. Additional surface assets, such as rovers, can also be powered from the same orbiting satellites, requiring only the additional mass of a receiver. However, the actual mass and power capabilities of the system are dependent on the location of the surface receiver. The masses of the bearn power systems can be reduced by up to $50 \%$, by using the power source of an electric propulsion vehicle to power the beam system. This paper discusses the important analyses results, and any additional issues that remain unresolved.
\end{abstract}

\section{INTRODUCTION}

Beam power was investigated as a technology to replace/supplement surface power systems for the Moon and Mars as part of the Space Exploration Initiative (SEI). A study was performed at NASA Lewis Research Center for the Lunar/Mars Exploration Project Office at NASA Johnson Space Center, to determine the feasibility of providing long term electrical power to the surface of the Moon or Mars from orbiting beam power satellites (based on the Solar Power Satellite - SPS concept). In addition, the important technology development requirements to enable the system feasibility were identified.

A beam power system for the Moon has several potential advantages when compared to surface power systems. Propulsion mass savings result, since the propellant to deliver the power source to the surface is not needed. Additionally, due to the 336 hour lunar night, $90 \%$ of the mass a solar power system is due to energy storage [1]. The beam power concepts can shorten the "eclipse" time, greatly reducing or eliminating the surface storage masses. Energy storage is only $52 \%$ of the martian surface solar power systems, because the night is only 12 hours long [2]. As a result, the potential advantages of power beaming for Mars may be limited. Further advantages of power beaming can be realized when using the power source of an electric propulsion orbital transfer vehicle as a "free" source of power for the beaming system, upon completion of the vehicle's cargo mission. Finally, because of the distributed nature of the beam power systems, easily deployednow mass power at remote sites becomes a possibility.

The approach of the study was to identify the subsystems and mission architectures, including all support subsystems such as thermal, structural and Power Management and Distribution (PMAD) to obtain a realistic end to end system mass. Using a spreadsheet model developed for this study, trade-off studies and system mass optimizations were performed. Having gained an understanding of the systems, preliminary reference beam power concepts for single and multiple surface bases and rovers were developed. The reference systems were then compared to solar and nuclear surface power systems.
This paper presents an overview of the results from earlier work based primarily on the Moon (for details see [3,4,5]). The analysis is expanded to include the powering of Mars bases, and a Nuclear Electric Propulsion/Solar Electric Propulsion (NEP/SEP) synergism. The masses in this paper are presented as the initial mass in low Earth orbit, and as a result, the masses are dependent upon the choice of propulsion system. Therefore, the lunar and martian masses cannot be compared equally, because the propulsion requirements to deliver the power systems from low Earth orbit are significantly different $[6,7,8]$. Finally, operational issues which have not been addressed in this study, but may impact the final decisions on the feasibility of beaming power to the Moon or Mars will be introduced.

\section{ASSUMPTIONS AND GROUNDRULES}

For innovative power systems such as power beaming, following the power profile of the conventional surface systems may limit its capabilities. The use of power beaming may enable new missions with higher power levels, or additional surface sites. All of the power levels for the cases discussed in this paper are for a complete constellation of satellites, without any consideration for power growth.

To size the transmitter and receiver apertures of the systems, a near field approximation was used:

$$
\frac{P_{r}}{P_{r}}=1-e^{\frac{A_{r} A_{l}}{(\lambda h)^{2}}}
$$

Where:

$$
\begin{aligned}
& \mathrm{h}=\text { Transmission Distance }(\mathrm{m}) \\
& \lambda=\text { Transmission Wavelength }(\mathrm{m}) \\
& A_{\mathrm{t}}=\text { Transmitter Area (Normal to Beam } \mathrm{m}^{2} \text { ) } \\
& A_{\mathrm{r}}=\text { Receiver Area (Normal to Beam } \mathrm{m}^{2} \text { ) } \\
& \mathrm{P}_{\mathrm{t}}=\text { Transmitted Power }(w) \\
& \mathrm{P}_{\mathrm{r}}=\text { Received Power }(w)
\end{aligned}
$$

The specific masses, conversion efficiencies and operating temperature assumptions for the orbiting beam power subsystems are presented in Table I. The "mid term" technology level assumptions, extrapolated from presently achieved laboratory components, represent an integrated flight system in 2005, requiring a system demonstration in the late 1990 's.

Both chemical and electric propulsion systems are considered for the transportation of the power systems to the Moon and Mars. A chemical propulsion system to the lunar environment assumes various combinations of expendable tanks with a lunar excursion vehicle [6]. An all chemical system was not used for the Mars transfer case. A combination of an electric propulsion cargo vehicle and a reusable chemical propulsion lunar/martian excursion vehicle was also considered $[6,7,8]$. The ratios of the initial mass in low Earth orbit (IMLEO) to the delivered mass for the various cases are shown below in Table II (LLO - Low Lunar Orbit, L1 Libration Point). 
TABLE I. MID TERM (2005 FLIGHT) TECHNOLOGY PERFORMANCE CHARACTERISTICS

\begin{tabular}{|c|c|c|c|}
\hline & $\begin{array}{l}\text { Specinc } \\
\text { Mass }\end{array}$ & Emiciency & $\begin{array}{l}\text { Operating } \\
\text { Temperature }\end{array}$ \\
\hline $\begin{array}{l}\text { Solar ATray } \\
\text { APSA - GaAs [9] }\end{array}$ & $3 \mathrm{~kg} / \mathrm{kw}$ & $22 \%$ & $300 \mathrm{~K}$ \\
\hline $\begin{array}{l}\text { Power Management and } \\
\text { Distribution [10] }\end{array}$ & $5 \mathrm{~kg} / \mathrm{kw}$ & $95 \%$ & $500 \mathrm{~K}$ \\
\hline $\begin{array}{l}\text { Microwive Transmines } \\
\text { Gypotros Tube [11] }\end{array}$ & $3 \mathrm{~kg} / \mathrm{kw} \quad 35 \mathrm{GHz}$ & $80 \%$ & $500 \mathrm{X}$ \\
\hline $\begin{array}{l}\text { Laser Transmitrer } \\
\text { Laser Diode Amay [12] }\end{array}$ & $\begin{array}{c}13 \mathrm{~kg} / \mathrm{mit}^{2} 3 \mathrm{~kg} / \mathrm{kw} \\
360 \mathrm{THz}\end{array}$ & $38 \%$ & $300 \mathrm{~K}$ \\
\hline $\begin{array}{l}\text { Microwave Antenna } \\
\text { Merallic Mesh Reflector [13] }\end{array}$ & $1 \mathrm{kght}$ & $100 \%$ & $300 \mathrm{~K}$ \\
\hline $\begin{array}{l}\text { Taseer Tranemissioa Optics } \\
\text { Gless Minor [14] }\end{array}$ & $170 \mathrm{~kg} / \mathrm{m}^{2}$ & $65 \%$ & $300 \mathrm{~K}$ \\
\hline $\begin{array}{l}\text { Microwave Recienna } \\
\text { Inregrated Technology }[11,15]\end{array}$ & $1.5 \mathrm{~kg} / \mathrm{m}^{2}$ & $85 \%$ & $500 \mathrm{~K}$ \\
\hline $\begin{array}{l}\text { Leser PV Receiver } \\
\text { Tuned GaAs Cells [14] }\end{array}$ & $3 \mathrm{~kg} / \mathrm{m}^{2}$ & $45 \%$ & $300 \mathrm{X}$ \\
\hline $\begin{array}{l}\text { Radiator } \\
\text { Gr/Al Compocite }[16,17]\end{array}$ & $5 \mathrm{~kg} / \mathrm{m}^{2}$ & $85 \%$ & $300-$ \\
\hline $\begin{array}{l}\text { Energy Siocage } \\
\text { Regenerative Fuel Cell [18] }\end{array}$ & \begin{tabular}{|c|} 
Fuel Cell - $14 \mathrm{~kg} / \mathrm{kw}$ \\
Electrolizer $-23 \mathrm{~kg} / \mathrm{kw}$ \\
$25 \mathrm{~kg}$ tunkage/kg reactant
\end{tabular} & $60 \%$ & $355 \mathrm{~K}$ \\
\hline $\begin{array}{l}\text { Energy Siorage } \\
\mathrm{N}-\mathrm{H}_{2} \text { Cells }[19,20]\end{array}$ & $\begin{array}{c}\text { Cells - } 20 \mathrm{~kg} / \mathrm{kwh} \\
\text { Packaging }-6 \mathrm{~kg} / \mathrm{kwh}\end{array}$ & $68 \%$ & $278 \mathrm{~K}$ \\
\hline $\begin{array}{l}\text { Unmanned Nuclear Reactor } \\
\text { Otbital SP-100 [21 22] }\end{array}$ & \multicolumn{3}{|c|}{$\begin{array}{l}17 \mathrm{~kg} / \mathrm{kwe} \text { (Includes reactor, coversion, } \\
\text { radiator, shield, and structure) }\end{array}$} \\
\hline
\end{tabular}

TABLE II. IMLEO/FINAL MASS DELIVERED RATIOS

\begin{tabular}{|c|c|c|}
\hline & Planetary Orbit & Planetary Surface \\
\hline \multicolumn{3}{|c|}{ Propulsion Systems to the Moon } \\
\hline Chernical & $2.8(\mathrm{~L} 1) / 3.5(\mathrm{LLO})$ & 4.5 \\
\hline Electric & $1.1(\mathrm{~L} 1) / 1.1(\mathrm{LLO})$ & 20 \\
\hline \multicolumn{3}{|c|}{ Propulsion Systems to Mars } \\
\hline Electric & 1.4 & 1.8 \\
\hline
\end{tabular}

Factors which may influence the use of beam power for Mars are the gases and dust elements in the Martian atmosphere. For the microwave frequency, little interference is expected in the 1 to 300 $\mathrm{GHz}$ range, however, for the laser frequencies, due to the presence of windbome Martian dust particles ranging from 0.1 to $30 \mu \mathrm{m}$ (mean radius $2.5 \mu \mathrm{m}$ ), scattering or blockage of the transmission may occur $[3,23]$.

\section{SYSTEM ANALYSIS OF ORBITING MICROWAVE AND LASER SYSTEMS}

\section{Systems Analysis of a Single Stationary Surface Site}

Initially, the mass analyses were performed for a single equatorial base. The resulting orbit scenarios are shown in figure 1 for the reference systems. For the lunar case, laser transmission ( $f=360$ THz, $\lambda=830 \mathrm{~nm}$ ) from the libration points (L1, 58,000 km) is possible from individual satellites that are in continuous view of the receiver. At the microwave frequencies $(f=35 \mathrm{GHz}, \lambda=0.85$ $\mathrm{cm}$ ), the antenna and rectenna sizes drive the mass optimizations to low lunar altitudes, where multiple equally phased satellites can provide complete coverage to the lunar base. Similarly, for the Mars base, the laser system optimizes at Mars synchronous orbit (MSO, 17,000 km), and the microwave system uses low martian orbits.

A solar array power source requiring no energy storage is lighter than the SP-100 nuclear reactor power source $(3 \mathrm{~kg} / \mathrm{kw}$ vs. 17 $\mathrm{kg} / \mathrm{kw})[9,21,22]$. However, in order to eliminate the need for energy storage on board the solar powered satellites, the orbit must be inclined to stay above the eclipse shadow, which results in larger receivers due to pointing losses. Also, the inclined orbit planes need to be precessed once per year.

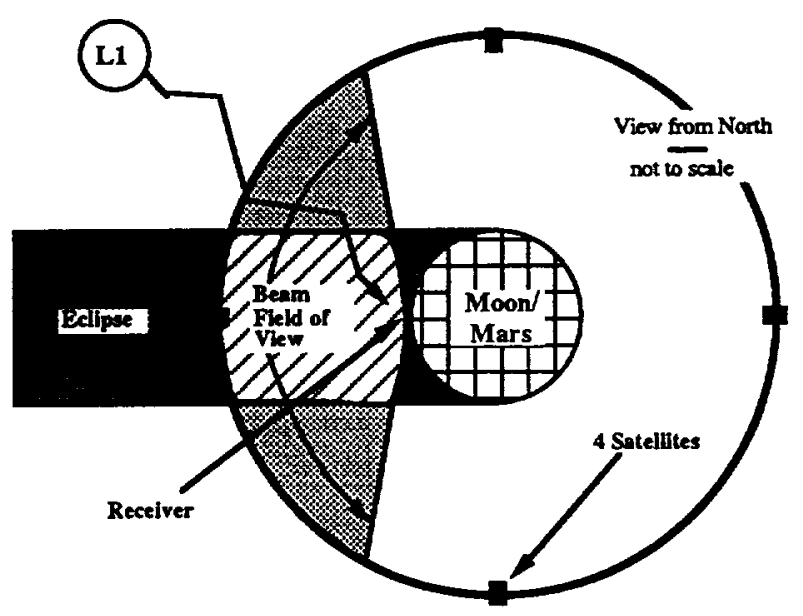

Figure 1. - Orbiting beam power satellites.

A trade was performed between the components whose masses depend on power level (power source, PMAD, and transmitter) verses the power independent components (antenna, rectenna, and laser optics), which depend primarily on the transmission frequency and distance. This mass optimization is dependent on the space transmission efficiency, $N_{l}$, which is the fraction of the transmitted energy collected by the receiver. As shown in figures 2 and 3 for a lunar base, in order to increase $N_{t}$, the transmitter/receiver areas must be made larger, adding power independent mass. The increased space transmission efficiency results in a higher end to end efficiency, decreasing the power dependent mass.

Because of this " $\mathrm{N}_{\mathrm{t}}$ Effect" the masses of the beam power systems may remain relatively constant with changes in the subsystem performance characteristics. As the frequency and power levels increase, the power dependent masses become a larger fraction of the system mass. For example, the high power laser systems are over $90 \%$ power dependent mass, and therefore have a well-defined minimum with respect to $\mathrm{N}_{\mathrm{t}}$ (figure 3 ). However, the microwave system mass is evenly distributed between power dependent and independent masses, and remains relatively constant over a wide region of transmission efficiencies $\left(0.2 \leq \mathrm{N}_{t} \leq 0.9\right.$ in figure 2). Each of the beam power systems has an optimum operating point, which is dependent upon the frequency and power level. At the power levels of the 90 Day study, the laser systems are closer to their optimum operating point than the microwave systems (i.e. laser at $\lambda=830 \mathrm{~nm}$ has an optimum power level at $\approx 100 \mathrm{kw}$, whereas the microwave at $35 \mathrm{GHz}$ optimizes at 1000 's of $\mathrm{kw}$ ). Therefore, in this region of power levels, the laser systems, although lighter, are more sensitive to changes in the performance characteristics than the microwave systems.

The microwave and laser system concepts were compared to the surface power systems for the Moon and Mars, as shown in figures 4 and 5 , for power levels ranging from $100 \mathrm{kw}$ to $1 \mathrm{Mw}$ for systems delivered to orbit by electric propulsion transportation vehicles. In the lunar case, the power beaming systems were $1 / 3$ to $1 / 6$ the mass of the surface solar systems, but were heavier than the surface nuclear systems. For the Mars base, because of the decreased impact of energy storage and propulsion savings, the systems are up to 2 times the mass of the surface systems for a single base.

Presently, concepts are being developed for SP-100 nuclear reactor and solar electric propulsion orbit transfer vehicles to ferry cargo from LEO to the Moon and/or Mars. An investigation was made in this study to determine the benefits of using an electric propulsion vehicle's power source as a "free" source of power for either a microwave or laser transmitter once the vehicle's cargo has been 


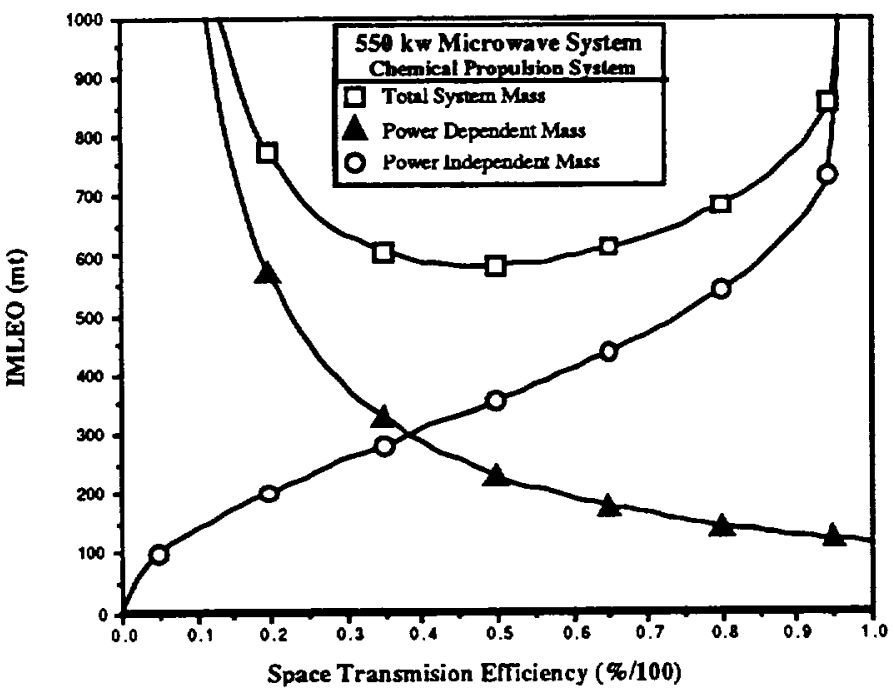

Figure 2. - Microwave $N_{t}$ optimization lunar base.

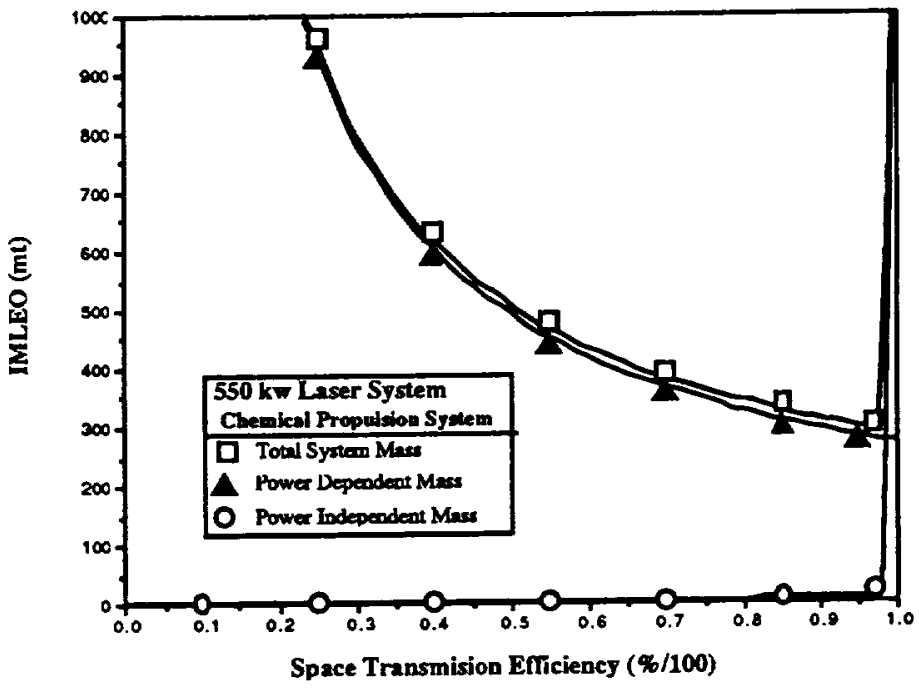

Figure 3. - Laser $\mathrm{N}_{t}$ optimization lunar base. delivered. The transmitter, PMAD and other supporting subsystems would be delivered as part of the electric propulsion vehicle's payload.

Using the NEP/SEP system eliminates the mass contribution of the reference beam power system's power source, by replacing it with the propulsion system's power source. Complete coverage is maintained by following the same orbit scenarios as the reference systems. As shown in figures 4 and 5 , the masses of the microwave reference systems would be reduced by 47 to $52 \%$ for the lunar and martian cases, while the laser systems would be reduced by $15 \%$ for the lunar case, and $27 \%$ for the martian case.

\section{System Analysis of Multiple Stationary Surface Sites}

For the microwave cases, in powering a single site, the power beamed from the satellites not in view of the base is wasted (See figure 6). Under the correct operating conditions, this extra power can be utilized by placing additional receivers at strategic locations, resulting in remote power capability for a small additional mass. Dedicated laser satellites power the main base, therefore additional satellites must be employed to power remote surface sites.

The mass of powering multiple microwave sites is dependent on the longitudinal separation distance of the surface sites. The number of satellites in the constellation determines the minimum separation distance required for continuous coverage of multiple sites. As shown in figure $6 \mathrm{a}$, at a lunar surface separation distance $\geq 90^{\circ}$ ( $\geq 72^{\circ}$ for Mars), a receiver is all that is needed. However, for the case shown in figure $6 \mathrm{~b}$, an overlap outage occurs if the sites are separated $<90^{\circ}$ $\left(<72^{\circ}\right.$ for Mars). Thus, either surface energy storage or additional satellites are needed for continuous operation at overlapping sites.

For a $550 \mathrm{kw}$ lunar site, the mass of a single site is 570 $\mathrm{mt}$ initial mass in low Earth orbit (chemical propulsion). For a second $550 \mathrm{kw}$ site, if the separation distance is $\geq$ $90^{\circ}$ (i.e. no overlap), a $110 \mathrm{mt}$ (IMLEO-chemical) receiver is all that is needed, for a total mass of $19 \%$ of the furst site. For separation distances $<90^{\circ}$, the overlap outage time will determine the mass of the energy storage system needed for continuous coverage. As the separation distance decreases, the energy storage mass

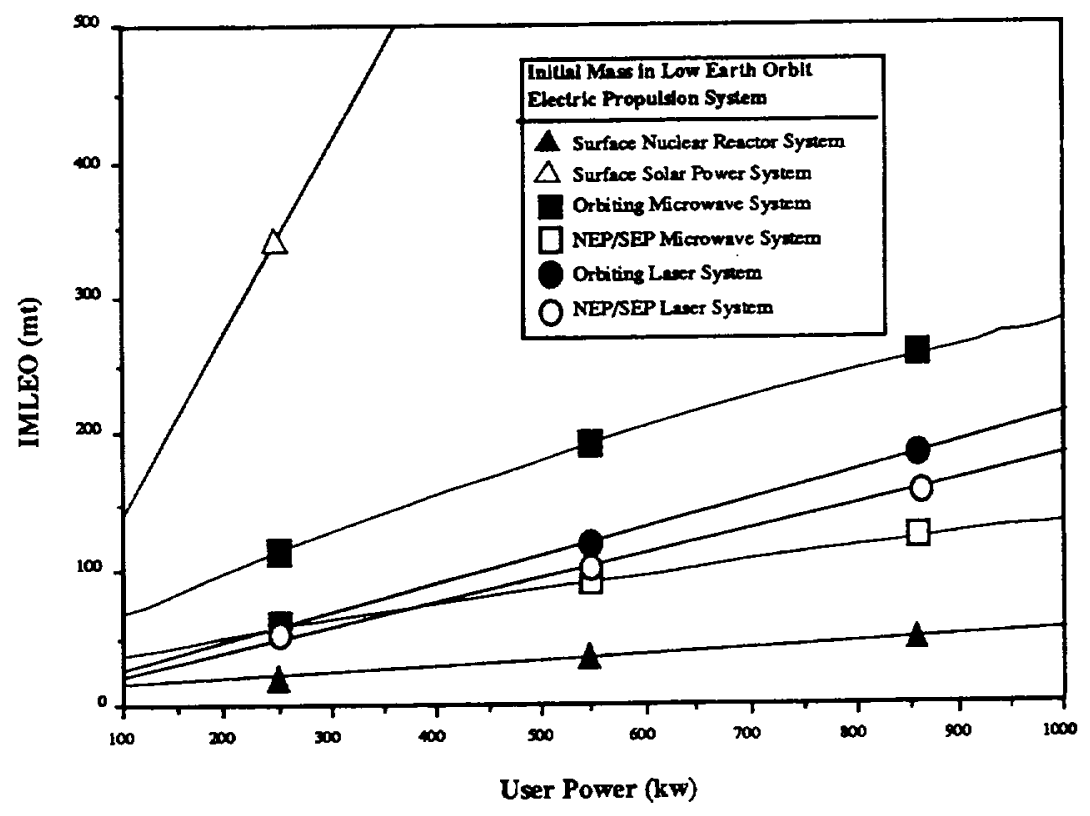

Figure 4. Lunar power system masses.

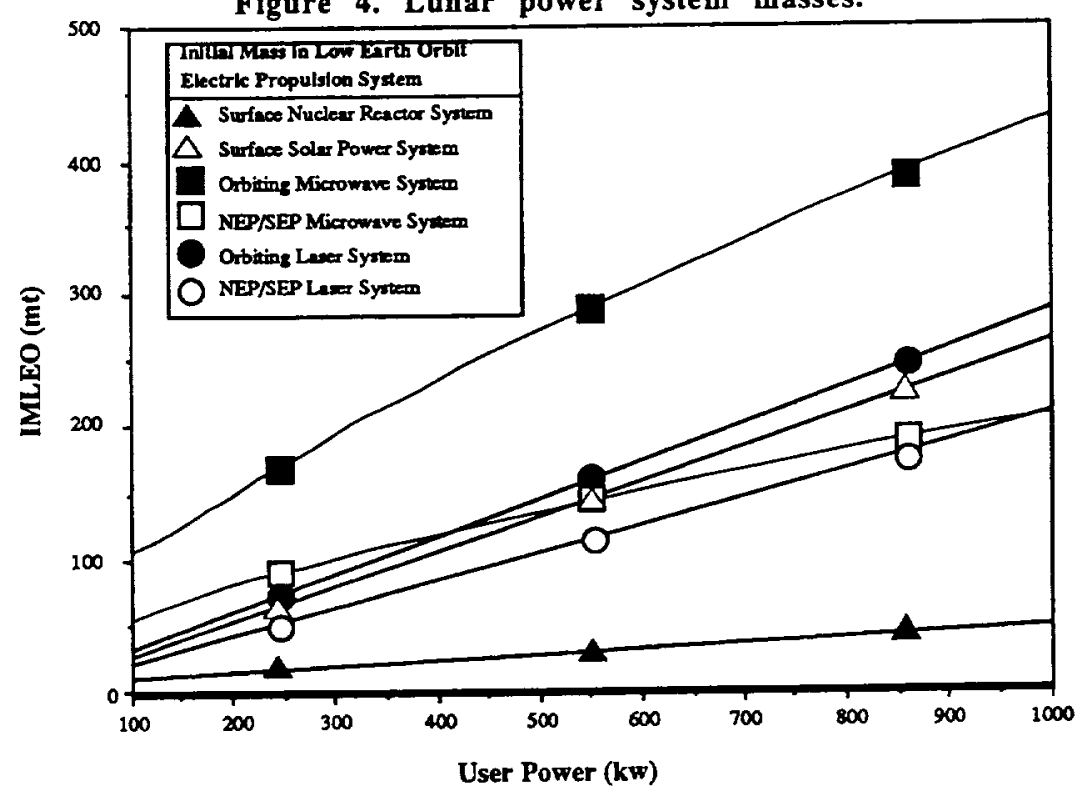

Figure 5. Martian power system masses. 
will increase, to the point where it is lighter to place a second dedicated constellation of satellites in orbit.

\section{System Analysis of Rover Vehicles}

Throughout this analysis, the systems have been optimized for lowest mass, resulting in large transmitters and receivers. As a result, a beam power system for powering a rover may have to be redesigned because of constrained receiver size requirements. If the rover power requirements per unit area of receiver are greater than what the mass optimized system can deliver, the system design must be modified. To increase the power density at the receiver, the satellite pointing accuracy, output power, and/or transmission frequency must be increased. In addition, for the solar powered microwave cases, the use of a dual axis tracking receiver can eliminate the power loss due to off normal pointing, however dual axis tracking rectennas are limited in area.

If, for example, the receiver area for a rover vehicle is limited to $100 \mathrm{~m}^{2}$, the laser system will not be affected, but the microwave system will due to the lower transmission frequency. The factor that drives the laser system areas is the pointing accuracy compensation $(\Delta)$, which offsets the combination of the jitter and other spacecraft disturbances.

Once again, assuming a $550 \mathrm{kw}$ microwave system (570 mt IMLEO - chemical), only $7.5 \mathrm{kw}$ of power can be produced by a $100 \mathrm{~m}^{2}$ rectenna at $35 \mathrm{GHz}$, as shown in figure 7. Increasing the source power to allow $1000 \mathrm{kw}$ at the main base, for a $262 \mathrm{mt}$ increase (IMLEO - chemical), will allow the powering of a $15 \mathrm{kw}$ rover. Similarly a $550 \mathrm{kw}$ martian system (307 mt IMLEO - electrical) can power a $5 \mathrm{kw}$ rover, as shown in figure 8 . Increasing the power to $1000 \mathrm{kw}$, for a $110 \mathrm{mt}$ increase (IMLEO-electrical), will allow the powering of a $7.5 \mathrm{kw}$ rover.

Another way to increase the power level is to increase the transmission frequency. If at $100 \mathrm{GHz}$, the transmitter times receiver efficiency can be sustained (i.e. $68 \%$ ), $30 \mathrm{kw}$ and $60 \mathrm{kw}$ can be provided to a martian and lunar rover respectively. Figures 7 and 8 show these relationships.

In general, however, increasing the frequency of transmission will result in a decrease in the efficiency of the transmitters. However, as shown by figure 9 , the system mass will remain constant as the frequency increases, because the increase in power dependent mass is offset by the decreased transmitter and receiver sizes. If the frequency is increased to $65 \mathrm{GHz}$, an $\mathrm{N}_{\mathrm{x}} * \mathrm{~N}_{\mathrm{r}}$ of $34 \%$ will result in antenna and rectenna area decreases of $29 \%$, with the mass remaining the same. Similarly, a $200 \mathrm{GHz}$ transmission frequency and $N_{x} * N_{r}$ of $17 \%$ will yield a reduction of $64 \%$.

\section{OPEN ISSUES FOR BEAM POWER FEASIBILITY}

The technologies that were assumed for the 2005 flight are extrapolated from research components which exist currently in the laboratory. However, there are many obstacles to be overcome before

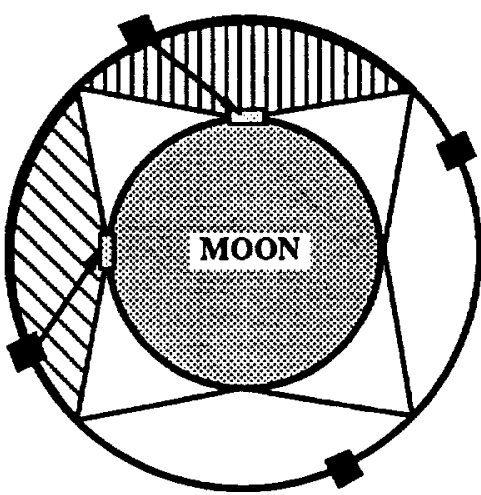

6a. Non-conflicting surface sites.

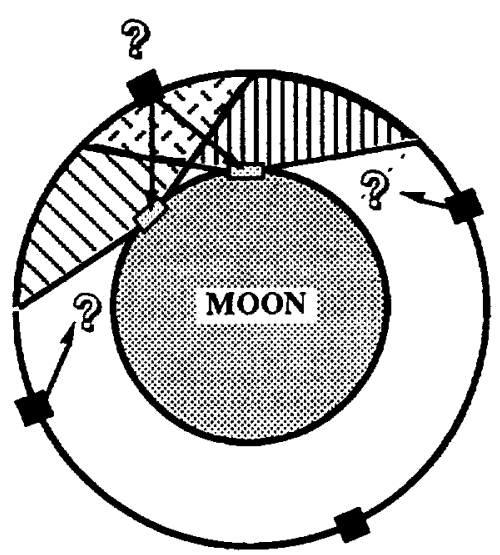

6b. Conflicting surface sites. Figure 6. - Overlapplng lunar surface sites.

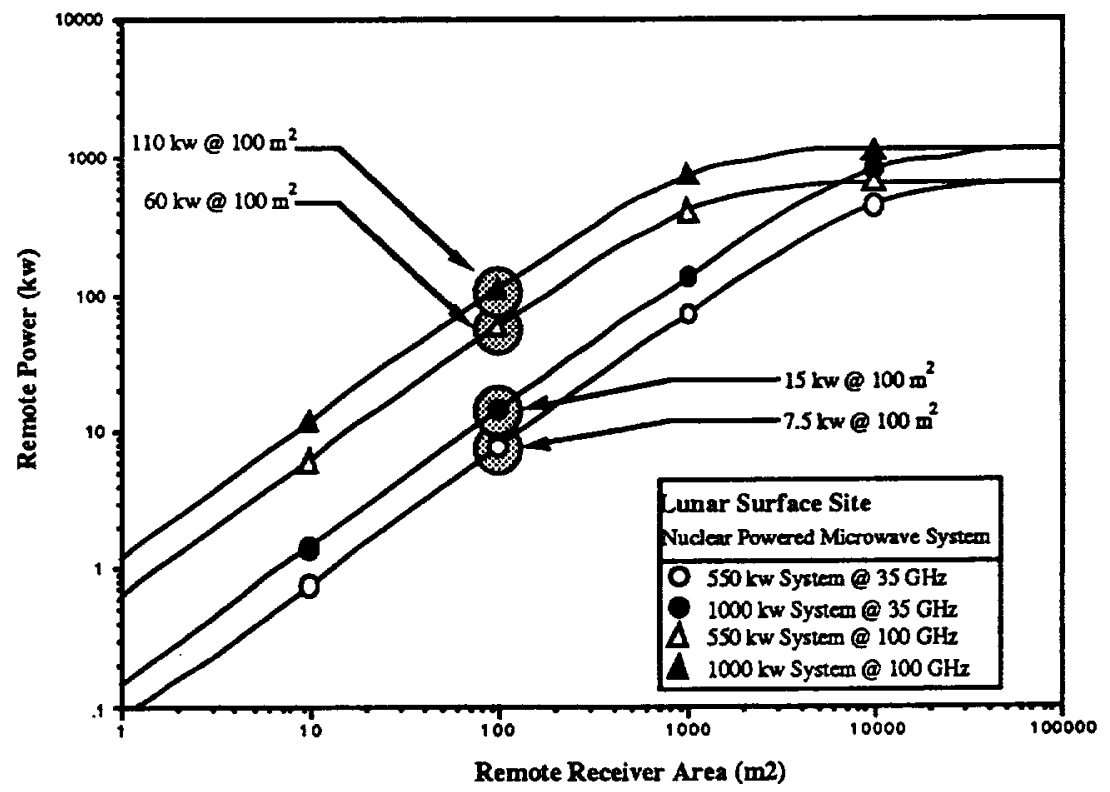

Figure 7. - Microwave nuclear source case lunar site power vs. rectenna area.

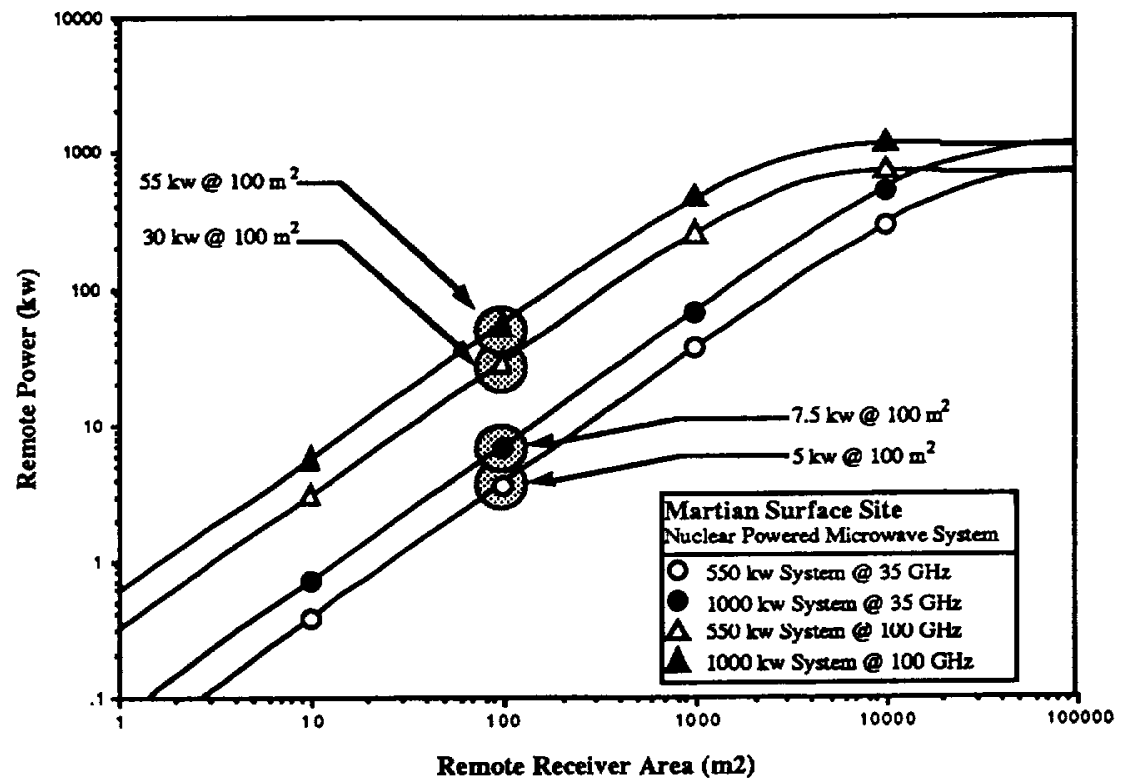

Figure 8. - Microwave nuclear source case martian site power vs. rectenna area. 


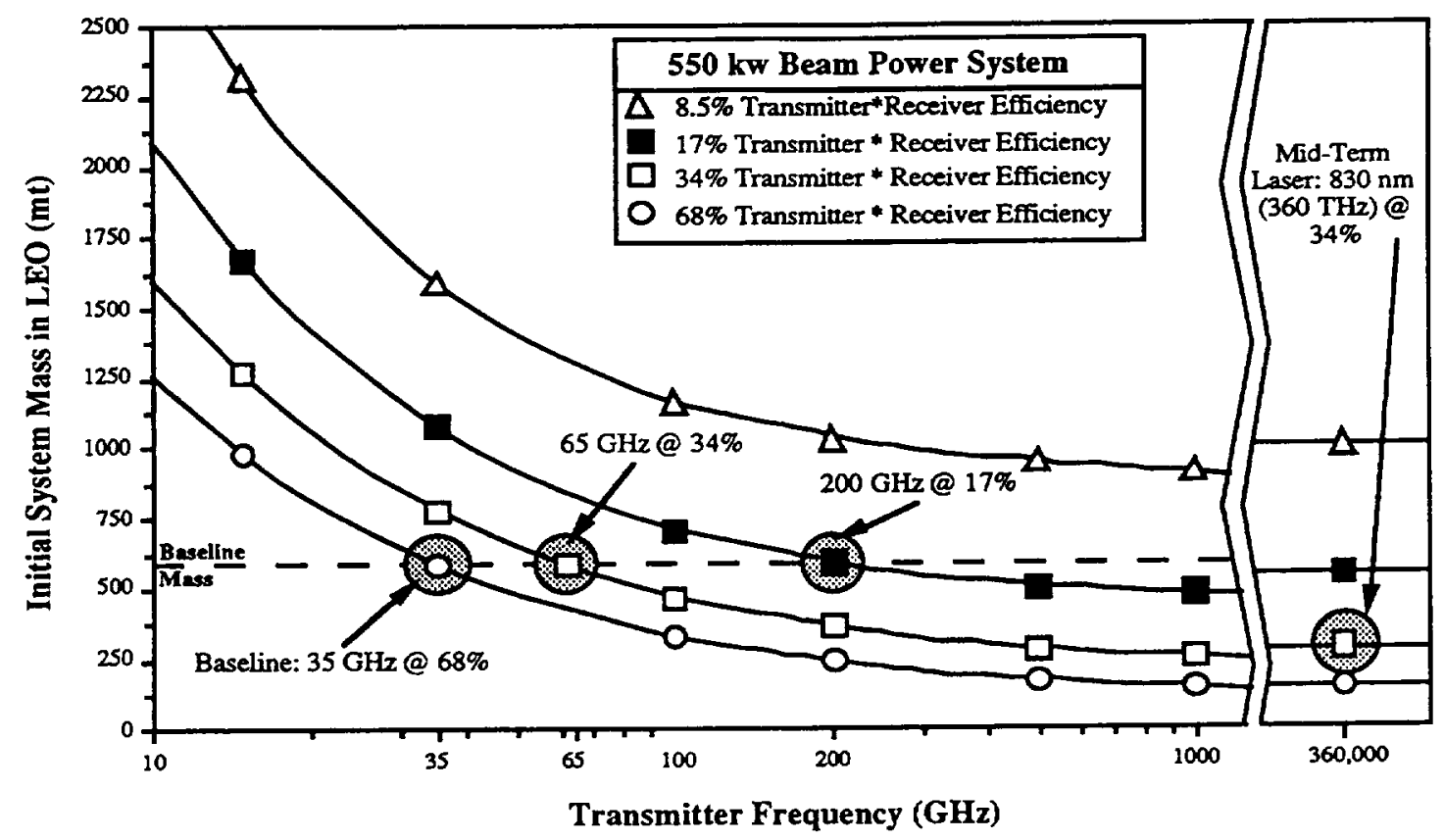

Figure 9. - Lunar system mass (IMLEO - Chemical) vs. transmitter frequency.

these technologies can be integrated into a flight system. For the laser diode array transmitter system, controlling the diodes to enable a coherent output beam has been demonstrated by the Air Force's PILOT program for a few diodes, however it is not easily scaleable to larger numbers of diodes [12]. In addition, the microwave gyrotron tubes may require additional support equipment, such as superconducting magnets, which were not accounted for in this analysis. Solid state transmitters can operate at "room" temperature, but their efficiency is probably limited to $\leq 50 \%$ [24]. Finally, a temperature drop between the radiators and the heat source was assumed to be zero, and an actual system may require larger radiators.

Possible improvements to the system resulting from additional system concepts, that take advantage of technology improvements, need to be explored, such as thin film solar cells and inflatable structures. However, the deployment and control of the very large solar arrays, radiators and antennas need to be analyzed. In addition, the transportation and operation of the satellites in orbit, including, satellite design, packaging, and launch vehicle requirements should be studied.

\section{CONCLUSIONS}

When supplying power to a single stationary surface base on the Moon or Mars, energy storage is the dominant mass. Beam power systems in orbit can be used to reduce or eliminate the energy storage requirements by decreasing the "eclipse" time. The lunar night is more extreme than the martian night, consequently, power beaming systems are lighter than surface solar systems for the Moon, but are heavier for Mars. In addition, for both the Moon and Mars, surface nuclear reactors are the lightest option.

Attaching the beam power system components to an electric propulsion vehicle, and using the vehicle's power source can significantly reduce the mass of the beam power systems. The mass reduction is approximately equal to the mass which the power source contributes to the reference system mass. However, the single base mass for the beam power systems is still heavier than the surface nuclear systems.
For single sites, each microwave satellite is "idle" for 75 to $80 \%$ of its orbit. Strategically placed remote sites need only a receiver to enable full use of the available power. Sites that are positioned close enough to result in an overlap of the satellite's fields of view, will require either surface energy storage or additional orbiting satellites for complete coverage.

A rover vehicle's power level is limited by its receiver area. The laser system, because of its $360 \mathrm{THz}$ transmission frequency, is not affected by this restriction. However, the baseline $35 \mathrm{GHz}$ microwave system can only beam $7.5 \mathrm{kw}$ to a lunar rover $(5 \mathrm{kw}$ for Mars). By increasing the frequency to $100 \mathrm{GHz}$, powering a $60 \mathrm{kw}$ lunar rover and a $30 \mathrm{kw}$ martian rover are possible.

To enable the feasibility of beam power for the Moon and Mars, the technology levels of the components must be increased from the current laboratory development levels. In addition, the on-orbit behavior and deployment of the very large space systems must be investigated. Finally, the operational requirements imposed by placing the power system in orbit must be considered.

\section{ACKNOWLEDGMENT}

This work was supported by the NASA Lewis Research Center under contract NAS3-25266. The author would like to acknowledge the significant contributions to this analysis by Ronald C. Cull of NASA Lewis Research Center and Edgar H. Fay of Sverdrup Technology, Inc.

\section{REFERENCES}

1. D.A. Petri, R.L. Cataldo, J.M. Bozek, "Power System Requirements and Definition for Lunar and Mars Outposts," Proceedings of the 25th IECEC, pp. 22-23, August 1990.

2. B.I. McKissock, L.L. Kohout, P.C. Schmitz, "A Solar Power System for an Early Mars Expedition," NASA-TM 103219. August 1990.

3. E.H. Fay, R.C. Cull, M.W. Stavnes, "Beam Power Systems for the Moon," Proceedings of the SPS 91, Power From Space Second International Symposium, August 1991. 
4. E.H. Fay, R.C. Cull, "Lunar Orbiting Microwave Beam Power System," NASA-TM 103211, August 1990.

5. M.W. Stavnes, R.C. Cull, "A Mass Sensitivity Analysis of Lunar Orbiting Beam Power Systems," Proceedings of the 26th IECEC, August 1991.

6. J.M. Woytach, "Lunar Transportation System Applicability for an Orbiting Beam Power System," Internal Memorandum, NASA Lewis Research Center, Cleveland, Ohio, April 1991.

7. R.C. Cull, K.A. Faymon, "Orbit to Surface Beamed Power for Mars Bases Expansion," Proceedings of the 24th IECEC, August 1989.

8. D.G. Andrews, "Near-term Nuclear Space Missions," Proceedings of the IAF International Conference on Space Power, Cleveland, Ohio, June 1989, pp. 285 - 306.

9. P.M. Stella, "Latest Developments in the Advanced Photovoltaic Solar Array Program," Proceedings of the 25th IECEC, pp. 571, August 1990.

10. K. Metcalf, R.B. Harty, J.F. Robin, "Issues Concerning Centralized vs. Decentralized Power Deployment," NASA Contractor Report, Rockwell International, Rocketdyne Division, March 1991.

11. K. Chang, "Feasibility Study of $35 \mathrm{GHz}$ Microwave Transmission in Space," Proceedings of the IAF Conference on Space Power, Cleveland, Ohio, June 5-7, 1989, pp. 369.

12. High Power Laser Diode Power Beaming Workshop, Batelle Seattle Research Center, Seattle, Washington, September 25-26, 1990.

13. M. Mikulas, "Structural Concepts for Very Large (400-Meter Diameter) Solar Concentrators," Proceedings of the Second Space Power Workshop, NASA-CP 3037, p. 253.

14. E.P. Coomes, J.A. Bamberger, L.A. McCauley, "An Assessment of the Impact of Free Space Electromagnetic Energy Transmission on Strategic Defense Initiative Systems and Architectures," May 1989.

15. A.J. Colozza, "Design and Optimization of a Self Deploying Photovoltaic Tent Array," NASA CR-187119, June 1991.

16. D.L. McDarels, K.W. Baker, D.L. Ellis, "Graphite Fiber/Copper Matrix Composites for Space Power Heat Pipe Fin Applications," 8th Symposium on Space Nuclear Power, Albuquerque, New Mexico, January 6-10, 1991.

17. "Evaluation of Advanced Composite Satellite Radiators," Technical Progress Report, MSCTPR 2118/8601, Materials Science Corporation, March 1990, pp. 10,18.

18. L.L.Kohout, "Cryogenic Reactant Storage for Lunar Base Regenerative Fuel Cells," NASA-TM 101980, June 1990.

19. R.J. Haas, A.K. Chawathe, G. van Ommering, "Space Station Battery System Design and Development," Proceedings of the 23rd IECEC, pp. 577-582, August 1988.

20. P. O'Donnell, "Energy Storage - A Short Course," Presented at the AIAANOAI Conference on Advanced Space Exploration Initiative Technologies," September, 1991.

21. L.S. Mason, H. Bloomfield, "SP-100 Power System Conceptual Design for Lunar Base Applications," NASA-TM 102090, p. 8, January 1989.

22. L.O. Cropp, D.R. Gallup, A.C. Marshall, "Mass and Performance Estimates for 5 to $1000 \mathrm{kw}(e)$ Nuclear Reactor Systems for Space Applications," Sandia Report SAND900312, March 1991, p. 47.
23. K.J. Long, "Analysis of a Mars Stationary Orbiting Microwave Power Transmission System," NASA-TM 101344, p. 6, July 1990.

24. Personal Conversation, Ed Hoagland, Space Electronics Division, NASA Lewis Research Center 

- 


\begin{tabular}{|c|c|c|c|c|}
\hline \multicolumn{3}{|c|}{ REPORT DOCUMENTATION PAGE } & & $\begin{array}{l}\text { Form Approved } \\
\text { OMB No. 0704-0188 }\end{array}$ \\
\hline \multicolumn{5}{|c|}{ 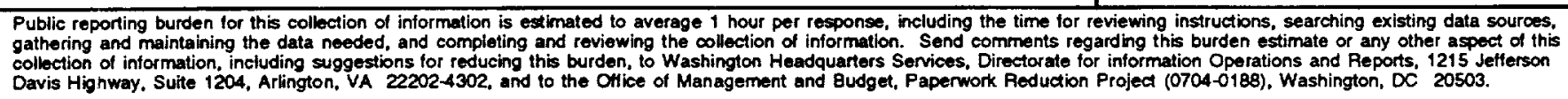 } \\
\hline 1. AGENCY USE ONLY (Leave blanK) & $\begin{array}{r}\text { 2. REPOATDATE } \\
\text { August } 1992\end{array}$ & \multicolumn{3}{|c|}{$\begin{array}{l}\text { 3. REPOAT TYPE AND DATES COVEAED } \\
\text { Final Contractor Report }\end{array}$} \\
\hline \multicolumn{3}{|c|}{$\begin{array}{l}\text { 4. TITLE AND SUBTTLE } \\
\text { An Analysis of Power Beaming for the Moon and Mars }\end{array}$} & \multirow{2}{*}{\multicolumn{2}{|c|}{$\begin{array}{l}\text { 5. FUNDING NUMBERS } \\
\text { WU-506-41-41 } \\
\text { C-NAS3-25266 }\end{array}$}} \\
\hline \multicolumn{3}{|l|}{$\begin{array}{l}\text { 6. AUTHOR(S) } \\
\text { Mark W. Stavnes }\end{array}$} & & \\
\hline \multicolumn{3}{|c|}{$\begin{array}{l}\text { Sverdrup Technology, Inc. } \\
\text { Lewis Research Center Group } \\
2001 \text { Aerospace Parkway } \\
\text { Brook Park, Ohio } 44142\end{array}$} & \multicolumn{2}{|c|}{ E-7581 } \\
\hline \multicolumn{3}{|c|}{$\begin{array}{l}\text { 9. SPONSORINGMONITORING AGENCY NAMES(S) AND ADDRESS(ES) } \\
\text { National Aeronautics and Space Administration } \\
\text { Lewis Research Center } \\
\text { Cleveland, Ohio } 44135-3191\end{array}$} & 10. $s$ & $\begin{array}{l}\text { NSORINGMONITORING } \\
\text { NCY REPORT NUMBER } \\
\text { SA CR-191072 }\end{array}$ \\
\hline \multicolumn{5}{|c|}{$\begin{array}{l}\text { Project Manager, Robert Bercaw, Power Technology Division, NASA Lewis Research Center, (216) 433-6112. Prepared } \\
\text { for the 27th Intersociety Energy Conversion Engineering Conference, San Diego, California, August 3-7, } 1992 .\end{array}$} \\
\hline $\begin{array}{l}\text { 12a. DISTRIBUTION/AVAILABILIT } \\
\text { Unclassified - Unlimited } \\
\text { Subject Category } 18\end{array}$ & STATEMENT & & \multicolumn{2}{|c|}{ 12b. DISTRIBUTION CODE } \\
\hline \multicolumn{5}{|c|}{$\begin{array}{l}\text { Operations on the surface of the Moon and Mars will depend on a reliable source of electrical power. At NASA } \\
\text { Lewis Research Center, the feasibility of powering lunar and martian surface sites by power beaming was studied. } \\
\text { Constellations of nuclear or solar powered satellites using microwave or laser transmitters were designed to power an } \\
\text { equatorial surface base. Additional surface assets, such as rovers, can also be powered from the same orbiting } \\
\text { satellites, requiring only the additional mass of a receiver. However, the actual mass and power capabilities of the } \\
\text { system are dependent on the location of the surface receiver. The masses of the beam power systems can be reduced } \\
\text { by up to } 50 \text { percent, by using the power source of an electric propulsion vehicle to power the beam system. This } \\
\text { paper discusses the important analyses results, and any additional issues that remain unresolved. }\end{array}$} \\
\hline \multirow[t]{2}{*}{$\begin{array}{l}\text { 14. SUBJECT TERMS } \\
\text { Mictowave; Laser, Power }\end{array}$} & & & & $\begin{array}{c}\text { 15. NUMBER OF PAGES } \\
8\end{array}$ \\
\hline & & & & $\begin{array}{l}\text { 16. PRICE CODE } \\
\text { A02 }\end{array}$ \\
\hline $\begin{array}{l}\text { 17. SECURITY CLASSIFICATION } \\
\text { OF REPORT } \\
\text { Unclassified }\end{array}$ & $\begin{array}{l}\text { 18. SECURITY CLASSIFICATION } \\
\text { OF THIS PAGE } \\
\text { Unclassified }\end{array}$ & $\begin{array}{l}\text { 19. SEC } \\
\text { OF }\end{array}$ & ATION & 20. LIMITATION OF ABSTRACT \\
\hline
\end{tabular}

